\title{
耐震設計に用いるジオグリッドの引張強さに関する一考察
}

\author{
三井化学産資株式会社 研究所 平井貴雄・谷津 淳
}

一般に，引張補強材として使用されるジオグリッドの設計引張強さは，引張試験で得られた引張強 さにクリープを考慮した低減係数を乗じた值が用いられている，一方，高分子材料であるジオグリッ ドの引張特性は, 引張速度に依存し, 地震時の載荷条件のように引張速度が速い場合, 大きな引張強 さを発現することが知られている.しかし，ジオグリッドの耐震設計に用いる設計引張強さを，実験 的に求める試験法は未だ標準化されておらず, 実際の設計では常時と地震時の設計引張強さは, 同じ 值が用いられていることが多いのが現状である.

地震時のジオグリッドの設計引張強さを考える場合には, ジオグリッドに常時の荷重が載荷されク リープ現象が生じた後の引張特性が問題となる．この引張特性は, ジオグリッドの素材や形態, クリ ープ現象を生じさせる常時の荷重, クリープ現象を生じさせる時間, 地震時にジオグリッドに作用す る引張力の引張速度などに依存すると考えられる.

本研究では, ジオグリッドに常時の荷重が載荷されクリープ現象が生じた後の引張特性について検 討し, 地震時の設計引張強さを評価する方法について考察を行った.

キーワード : 設計引張強さ, 而震設計, クリープ現象

\section{Evaluation Method about Tensile Strength of Geogrid to use for Dynamic Design}

T.Hirai and A.Yatsu : Research Laboratory, Mitsui Petrochemical Industrial Products, LTD,

Generally, as for the design tensile strength of geogrid used as reinforcement material, tensile strength is decided considering creep characteristic. It is also known that the tensile characteristic of geogrid made of polymer material depends on the elongation rate showing large tensile strength under high elongation rate. On the other hand, some methods of evaluating the design tensile strength for a dynamic design are proposed by some organizations. However, those methods aren't yet standardized. Realistically in such reason, the design tensile strength for the static design is also used for the dynamic design. When thinking of the design strength of geogrid in case of dynamic loading, tensile characteristics after creep phenomenon occurs by static load are a problem. Its characteristics depend on static load to make creep phenomenon occur, continuing time, elongation rate which acts on geogrid in case of the earthquake and so on. In this research, the tensile characteristics of geogrid after a creep phenomenon by the static load are tested. The techniques of the data gathering and evaluation, which is the basis about the setting of dynamic design tensile strength, are considered.

Keyword: Design tensile strength, Dynamic design, Creep phenomenon 


\title{
耐震設計に用いるジオグリッドの引張強さに関する一考察
}

\author{
三井化学産資株式会社 研究所 平井貴雄・谷津 淳
}

1.はじめに

現在，壁高の高いジオグリッド補強土壁の設計では，そのほとんどが耐震設計により，ジオグリッ ドの配置などの構造が決定されているのが現状である. また, 1995 年の阪神大震災において, 激震地 に建設されたジオグリッド補強土壁の多くは，ほとんど損傷を受けておらず，ジオグリッド補強土壁 が，耐震性の高い構造物であることが証明され，注目を集める結果となった．近年では，このような 背景により，ジオグリッド補強土壁の耐震性評価に関する研究や新しい補強土壁構造の提案が盛んに 行われている.

一方, 補強材として使用されるジオグリッドの設計引張強さは, 常時の設計では一般に, クリープ を考虑し，強度低隇を行った值が用いられている．これに対し，高分子材料であるジオグリッドの引 張特性は，引張速度に依存し，地震時の載荷条件のように引張速度が速い場合は，大きな引張強さを 発現することが古くから知られている。しかし，耐震設計におけるジオグリッドの設計引張強さを考 える場合には，ジオグリッドに常時の荷重が載荷されクリープ現象が生じた後の引張特性が問題とな る.このクリープ現象が生じた後の引張特性は, クリープ現象を生じさせる常時の荷重, クリープ現 象を生じさせる時間，地震時にジオグリッドに作用する引張力の引張速度などに依存すると考えられ る。しかし，現時点では，このような影響因子を考慮し，耐震設計に用いる設計引張強さを実験的に 求める試験方法は確立されておらず, また, 個々のジオグリッドについての特性は明らかでないため, 実際の設計では常時と地震時の設計引張強さは, 同じ值が用いられることが多い.

本研究では, ジオグリッドに常時の荷重が載荷されクリープ現象が生じた後の引張特性について検 討し，耐震設計での設計引張強さを評価・設定する方法について考察を行った.

\section{2． 地震時のジオグリッドの設計引張強さ}

2.1 設計マニュアルでの取り扱い

現在, 補強土壁工法の設計法として, 最も多く活用されている“ジオテキスタイルを用いた補強土 の設計・施工マニュアル（改訂版）”1)では，高分子材料であるジオテキスタイルは，引張速度が速く なるほど引張剛性・引張強さとも大きな值を示す傾向が認められており ${ }^{2)}$, 常時設計に用いられるク リープを考慮したジオテキスタイルの設計引張強さに対して，耐震設計では，以下のような関係から 設計引張強さを定めることができるとされている．また，(2.1)式の割増係数入については，常時に負 荷される荷重履歴や地震時の荷重を想定し, 合理的と判断される試験方法により求める必要があると されている. 


$$
\begin{aligned}
& T_{A E}=\lambda \cdot T_{A} \quad(2.1) \\
& \text { ここで， } \quad T_{A E} \quad \text { ： 耐震設計に用いるジオテキスタイルの設計引張強さ }(\mathrm{kN} / \mathrm{m}) \\
& T_{A} \quad \text { ： 常時設計に用いるジオテキスタイルの設計引張強さ }(\mathrm{kN} / \mathrm{m}) \\
& \lambda \quad \text { : ジオテキスタイルの耐震設計用引張強さの常時設計用引張強さに } \\
& \text { 対する割增し係数 }
\end{aligned}
$$

\section{2 耐震設計でのジオグリッドの設計引張強さについての基本的な考え方}

補強土壁の常時の設計に用いるジオグリッドの設計引張強さは，一般的に，(2.2)式により，決定さ れており, 静的な荷重を想定した定速での引張試験で求められる最大引張強さを各種の材料安全率で 除した值が用いられている， ${ }^{3)}$ また，この最大引張強さを求める試験法としては，一般的に，次のよ うな考え方に従って条件を設定している. ジオグリッドの引張特性は, 試験時の引張速度に依存する ため, 土構造物の補強材として適用する場合には，施工中に発生する土の変形のひずみ速度や，土構 造物が静的安定に至るまでの変形速度を考慮して適切に決定することが望ましい. しかし，土変形の ひずみ速度は一様でないことから土の三軸圧縮試験でのひずみ速度 $(1 \% / \mathrm{min})$ と同じ引張速度を条件 とした性能評価試験が用いられている，4)

$$
\begin{aligned}
T_{A}=\frac{T_{\max }}{F_{c r} \cdot F_{D} \cdot F_{C} \cdot F_{B}} & =\frac{T_{c r}}{F_{D} \cdot F_{C} \cdot F_{B}} \quad(2.2) \\
\text { ここで, } T_{A} & : \text { ジオグリッドの設計引張強さ }(\mathrm{kN} / \mathrm{m}) \\
T_{\max } & : \text { ジオグリッドの最大引張強さ（製品基準強度） }(\mathrm{kN} / \mathrm{m}) \\
F_{c r} & : \text { クリープを考慮した材料安全率 } \\
F_{D} & : \text { 耐久性（耐候性, 耐薬品性等）を考慮した材料安全率 } \\
F_{C} & : \text { 施工中の損傷を考慮した材料安全率 } \\
F_{B} & : \text { 接続部の強度低下を考慮した材料安全率 } \\
T_{c r} & : \text { クリープを考慮したジオグリッドの限界引張強さ }(\mathrm{kN} / \mathrm{m})
\end{aligned}
$$

これに対して, ジオグリッドに常時の荷重が載荷されクリープ現象が生じた後の地震時の最大引張 強さ（引張特性）を表す特性値は，以下のような関数系で表されると考えられる.

$$
\begin{aligned}
& T_{E \max }=f\left(T_{\max }, T_{c}, t_{c}, s_{T}\right) \quad(2.3) \\
& \text { ここで, } \quad T_{E \max } \quad \text { ： 地震時の最大引張強さ }(\mathrm{kN} / \mathrm{m}) \\
& T_{c} \quad \text { ：クリープ現象を生じさせる常時の引張荷重 }(\mathrm{kN} / \mathrm{m}) \\
& \text { （以下では，クリープ載荷荷重と呼ぶ） } \\
& t_{c} \quad \text { ：クリープ現象を生じさせる時間 }(\mathrm{hr}) \\
& \text { （以下では，クリープ載荷時間と呼ぶ） } \\
& s_{T} \quad \text { ： 地震時の引張速度 }(\% / \mathrm{min})
\end{aligned}
$$

ここで, 最終的な評価の方法は, 現行の設計上の取り扱いから, (2.1)式の割増し係数 $\lambda$ による整理 が望ましい，このため, 耐震設計に用いるジオグリッドの設計引張強さ $T_{A E}$ についても，(2.2)式と同 様の(2.4)式の様に整理する. 


$$
T_{A E}=\frac{T_{\max }}{F_{E} \cdot F_{D} \cdot F_{C} \cdot F_{B}}=\frac{T_{E \max }}{F_{D} \cdot F_{C} \cdot F_{B}}
$$

$$
\text { ここで, } \quad F_{E}=\frac{T_{\max }}{T_{E \max }}
$$

$F_{E} \quad ：$ 地震荷重に対する材料安全率(常時の荷重によるクリープ現象を考慮)

したがって，(2.1)，(2.2)，(2.4)式より，割增し係数入は，(2.6)式のように表される.

$$
\lambda=\frac{F_{c r}}{F_{E}}(2.6)
$$

ここで, $F_{E}$ は, $(2.3)$ 式の $T_{E \max }$ と同様に, クリープ載荷荷重, クリープ載荷時間, 地震時の引張速 度の関数であると考えられ，割增係数入の評価には，これらの影響を把握しておく必要がある.

\section{3. クリープ載荷後の引張特性についての模型実験}

\section{1 試験方法}

(1) 試験装置および試験方法

試験装置の概略図を図-1に, 写真を写真-1に示す. 試験方法は, 空気圧によって下部のベロフラム シリンダーを用いて, 一定のクリープ載荷荷重 $\left(T_{c}\right)$ を一定の時間（クリープ載荷時間 $t_{c}$ ）継続的に 載荷して, 試験サンプルにクリープ現象を生じさせた後, 除荷することなく, 上部のスクリュージャ ッキにより, 一定の引張速度 $\left(s_{T}\right)$ で引張り, その引張特性, 最大引張荷重 $\left(T_{E}\right)$ を確認する.

(2) 試験ケース

2.2 で述べたように, ある常時の特性值を持つジオグリッド（常時の最大引張強さ $T_{\max }$, 常時の設計 引張強さ $T_{A}$ ）に対して, 耐震設計における設計引張強さ（割增し係数 $\lambda$ ）を評価するためには, クリ 一プ現象を生じさせる常時のクリープ載荷荷重 $\left(T_{c}\right)$, クリープ現象を生じさせるクリープ載荷時間 $\left(t_{c}\right)$, 地震時の引張速度 $\left(s_{T}\right)$ の引張特性への影響を把握しておく必要がある.

今回, それぞれの影響の度合いを定量的に評価するため, 表-1に示す特性值（常時の最大引張強さ など）を持つジオグリッドについてクリープ載荷後の引張試験を実施した。 また，クリープ現象を生 じさせる常時のクリープ載荷荷重 $\left(T_{c}\right)$ などの試験条件については表-2 および表-3に示すケースの試 験を行い, クリープ載荷を行わなかったジオグリッドの引張特性との比較を行った.

\section{2 試験結果}

（1）引張特性の引張速度依存性

図-2 は, クリープ載荷を行わない条件で, 引張速度を変化させて実施した引張試験の結果である. 今回使用した高密度ポリエチレン一軸延伸タイプのジオグリッドでは, 図に示すように引張速度が速 くなるほど, 引張荷重に対する抵抗值（最大引張荷重）が大きくなる傾向にあることがわかる.また， 図-3には, 引張速度とこの最大引張荷重の関係を示した。最大引張荷重は, 引張速度に依存し, 速度 が速いほど大きな最大引張荷重となる. 


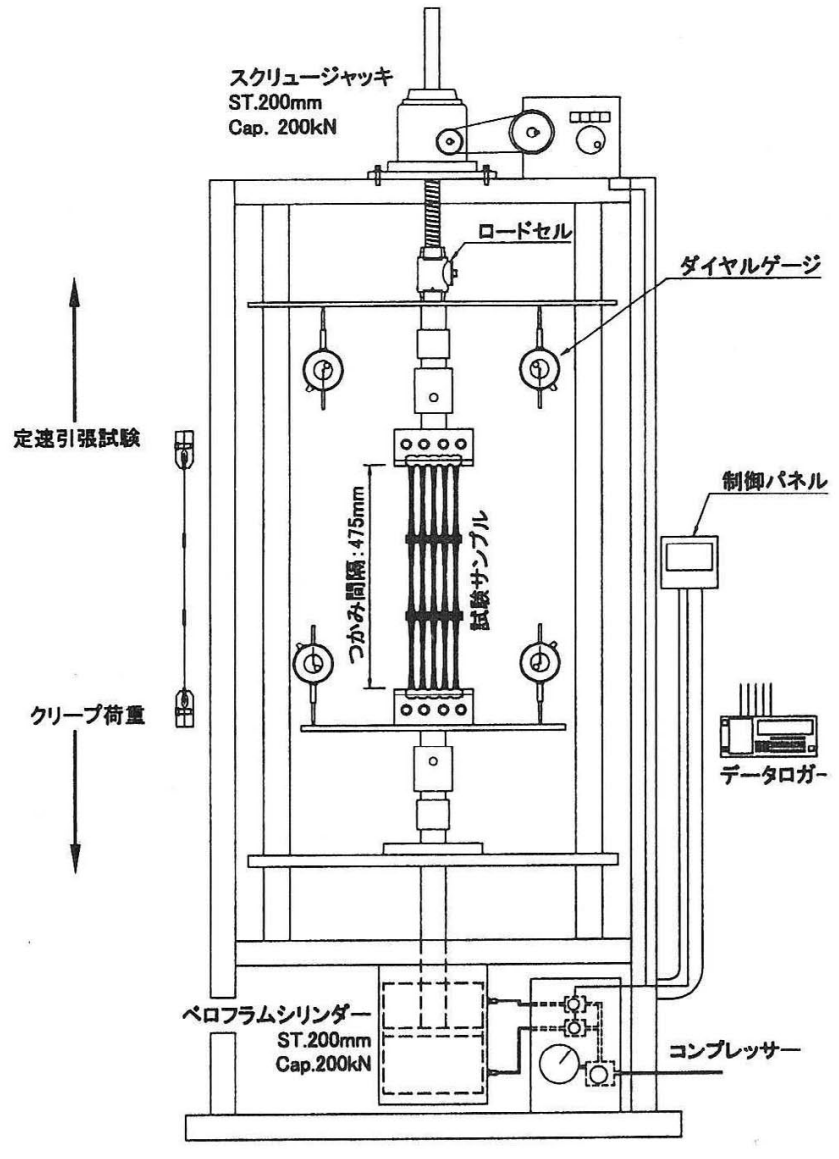

図-1 試験装置の概略図

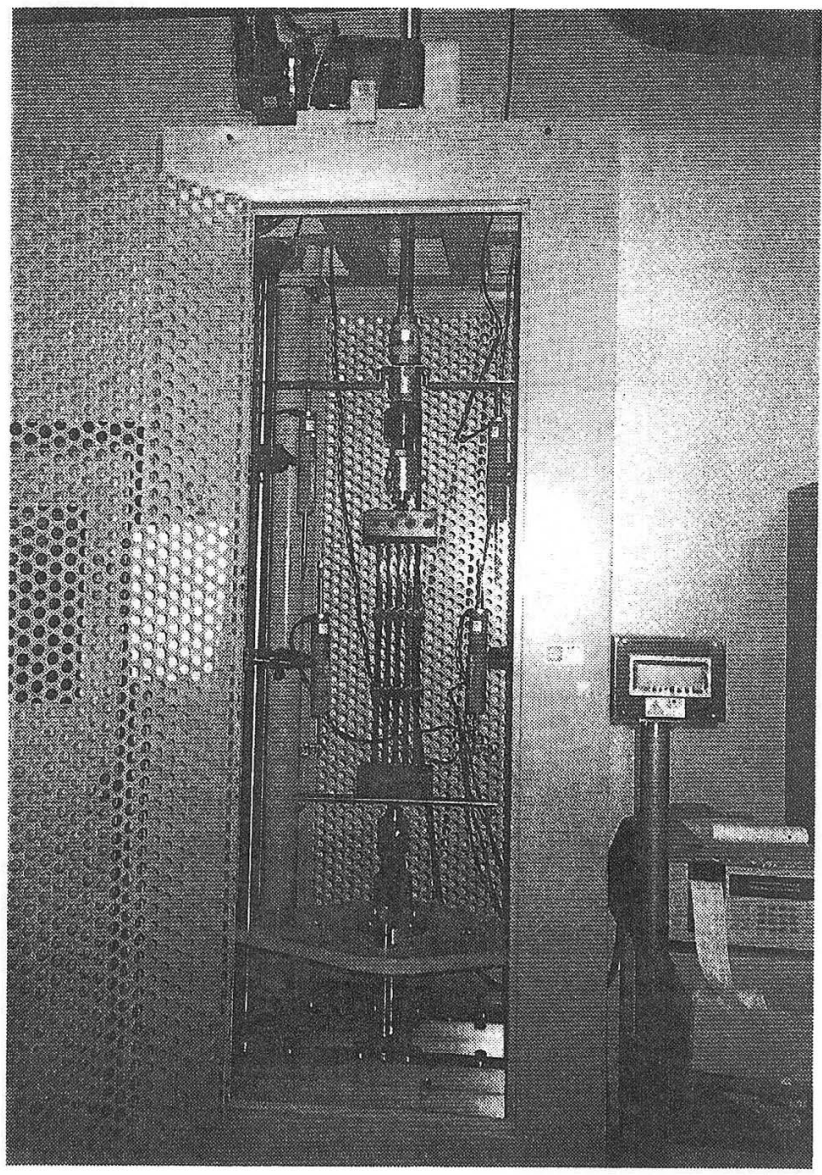

写真-1 試験装置
表-1 使用した試験サンプルの特性值

\begin{tabular}{|c|c|}
\hline 項 目 & 特性值 \\
\hline ジオグリッドの素材 & 高密度ポリエチレン \\
\hline ジオグリッドのタイプ & 一軸延伸タイプ \\
\hline 最大引張強さ (製品基準強度) 注 1) & $T_{\max }=50 \mathrm{kN} / \mathrm{m}$ \\
\hline $\begin{array}{c}\text { 常時の設計引張強さ 注 2) } \\
\text { (クリプを考慮した限界引張強さ) }\end{array}$ & $\begin{array}{r}T_{A}=T_{c r}=\mu T_{\max } \\
=30 \mathrm{kN} / \mathrm{m}\end{array}$ \\
\hline クリープ低隇係数 & $\mu=0.6$ \\
\hline クリープを考慮した材料安全率 & $F_{c r}=1 / \mu=1.67$ \\
\hline
\end{tabular}

注1) 広幅 $(22.2 \mathrm{~cm})$ サンプルによる低速の引張速度 $(1 \% / \mathrm{min})$ での引張試験の結果をもとに設定した引張強さ

注2) 便宜的にクリープ以外の材料安全率は, 1.0 を仮定.
表-2 クリープ載荷・定速引張の載荷条件

\begin{tabular}{|c|c|}
\hline 項 目 & 内 \\
\hline $\begin{array}{c}\text { クリープ載荷何重 } \\
\left(T_{c}\right)\end{array}$ & $\begin{array}{l}0.4 T_{\max }(=20 \mathrm{kN} / \mathrm{m}) \\
0.6 T_{\max }(=30 \mathrm{kN} / \mathrm{m})\end{array}$ \\
\hline $\begin{array}{c}\text { クリープ載荷時間 } \\
\left(i_{c}\right)\end{array}$ & $6,24,100,1000$ 時間 \\
\hline $\begin{array}{c}\text { 引張速度 } \\
\left(s_{T}\right)\end{array}$ & $\begin{array}{l}0.2 \% / \mathrm{min},, 1 \% / \mathrm{min}, \\
10 \% / \mathrm{min}, 20 \% / \mathrm{min}\end{array}$ \\
\hline
\end{tabular}

表-3 試験ケース

\begin{tabular}{|c|c|c|c|c|c|}
\hline \multirow{2}{*}{$\begin{array}{c}\text { クリープ } \\
\text { 載荷荷重 }\left(T_{c}\right)\end{array}$} & \multirow{2}{*}{$\begin{array}{c}\text { クリープ } \\
\text { 載荷時間 }\left(t_{c}\right)\end{array}$} & \multicolumn{4}{|c|}{ 定速引張鴿験での引張速度（ $\left.s_{T}\right)$} \\
\hline & & $0.2 \% / \mathrm{min}$ & $1 \% / \mathrm{min}$ & $10 \% / \mathrm{min}$ & $20 \% / \mathrm{min}$ \\
\hline- & - & 0 & 0 & 0 & 0 \\
\hline \multirow{4}{*}{$\begin{array}{c}0.4 \cdot T_{\max } \\
(=20 \mathrm{kN} / \mathrm{m})\end{array}$} & $6 \mathrm{hr}$ & $=$ & $=$ & 0 & 0 \\
\hline & $24 \mathrm{hr}$ & 0 & 0 & 0 & 0 \\
\hline & $100 \mathrm{hr}$ & 0 & 0 & 0 & 0 \\
\hline & $1000 \mathrm{hr}$ & - - & & $=$ & 0 \\
\hline \multirow{3}{*}{$\begin{array}{c}0.6 T_{\max } \\
(=30 \mathrm{kN} / \mathrm{m})\end{array}$} & $24 \mathrm{hr}$ & 0 & 0 & - & 0 \\
\hline & $100 \mathrm{hr}$ & - & - & - & 0 \\
\hline & $1000 \mathrm{hr}$ & - - & - & - & 0 \\
\hline
\end{tabular}


ここで, 一般に地震時にジオグリッドに作用する引張速度は, 通常の静的な定速载荷の引張試験条 件よりも速くなると推測されるが, 試験上, 数 $100 \% / \mathrm{min}$ 以上のオーダーの引張速度での載荷は困難 である.しかし，今回使用したジオグリッドの引張速度依存性を考虑した場合，比較的低速な引張速 度での実験を実施しておくことで, 安全側の評価を行うことができると考えられるため, 今回の一連 の評価では, 引張速度 $20 \% / \mathrm{min}$ の試験ケースを中心に検討を行った.

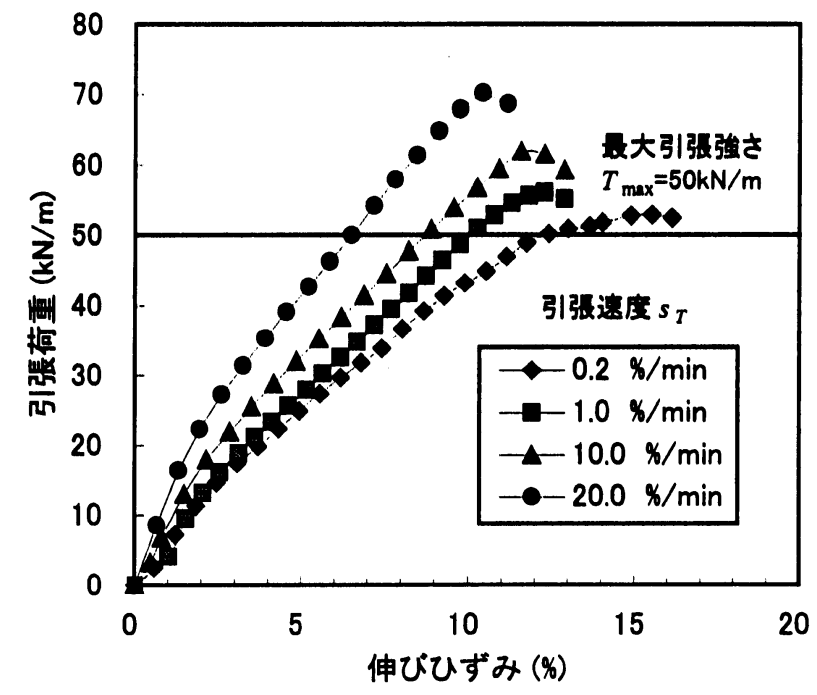

図-2 引張特性の引張速度の依存性

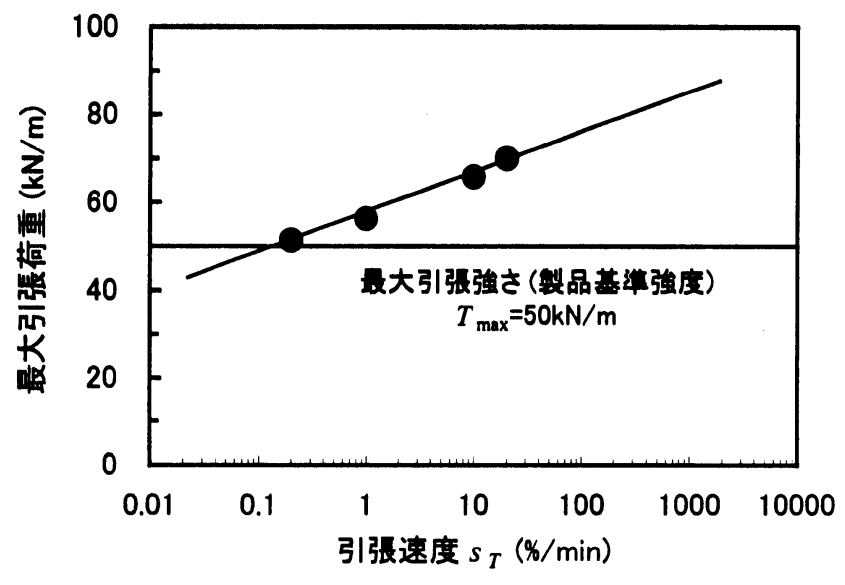

図-3 引張速度と最大引張荷重の関係

(2) クリープ載荷試験結果

クリープ載荷荷重 $\left(T_{c}\right)$ が, 常時の最大引張強さの $40 \%$ ある試験ケース $\left(T_{c}=0.4 \cdot T_{\max }=20 \mathrm{kN} / \mathrm{m}\right)$ のク リープ載荷時間 $\left(t_{c}\right)$ と伸びひずみ（クリープによる伸びひずみ）の関係を図-4に示す.なお, 図 -4 は, クリープ載荷後の定速引張試験の引張速度が $20 \% / \mathrm{min}$ の試験ケースで, クリープ載荷時間 $\left(t_{c}\right)$ が, 6 , 24, 100,1000 時間の 4 ケースの結果である. 図に示す通り, すべてのケースの曲線は, ほぼ一致して おり, クリープ載荷時間ごとにクリープによる最終伸びひずみの量が異なる. クリープ載荷時間 $t_{c}$

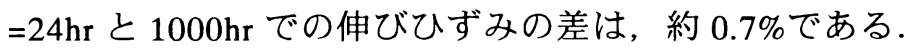

(3) クリープ載荷後のジオグリッドの引張特性

図-5 は, クリープ載荷荷重が常時の最大引張強さの $40 \%$ 荷重 $\left(T_{c}=0.4 T_{\max }\right)$ のケースについて, ク リープ載荷後(クリープ載荷時間 $t_{c}=6 \mathrm{hr}, 24 \mathrm{hr}, 100 \mathrm{hr}, 1000 \mathrm{hr}$ )の引張試験の結果を示したものであ る. また, 図-6 は, クリープ載荷荷重が常時の最大引張強さの $60 \%$ 荷重 $\left(T_{c}=0.6 T_{\max }\right)$ のケースにつ いて, クリープ載荷後（クリープ載荷時間 $t_{c}=24 \mathrm{hr}, 100 \mathrm{hr}, 1000 \mathrm{hr}$ )の引張試験の結果を示したもので ある.クリープ載荷終了時の伸びひずみの量に違いがあるため, 引張特性曲線（引張荷重と伸びひず みの関係）は，それぞれのケースで若干異なるが，最大引張荷重の值は，クリープ載荷を行わない条 件での値を含め, ほぼ同程度である，また，クリープ載荷時間が長い方が，曲線の傾き（剛性）がや 
や急で硬化していることが分かる.

また, 図-7 は, クリープ載荷時間が $1000 \mathrm{hr}$ のケースで, クリープ載荷荷重 $T_{c}=0.4 T_{\max }=20 \mathrm{kN} / \mathrm{m}$ および $T_{c}=0.6 T_{\max }=30 \mathrm{kN} / \mathrm{m}$ の引張荷重とクリープ現象による伸びひずみを含んだトータル伸びひず みとの関係を示したものである．図のようにクリープ載荷荷重によって，クリープによる伸びひずみ の量は異なるが, 最大引張荷重を発現するトータル伸びひずみの量は, ほぼ同じ值である.さらに, クリープ載荷を行っていないケースと比較し, クリープによる伸びひずみの量が多いケースほど, 引 張試験で得られた伸びひずみと引張荷重の関係曲線の傾き（剛性）が急になっていることが分かる.

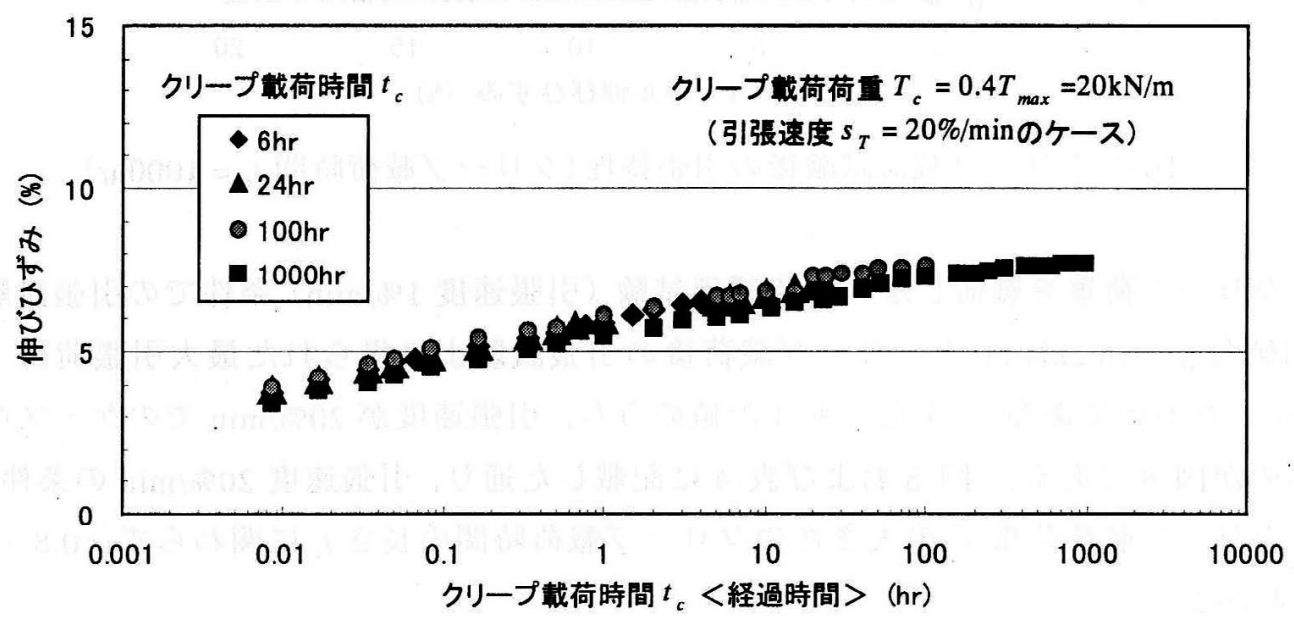

図-4 クリープ載荷時間 $\left(s_{T}\right)$ と伸びひずみの関係（載荷荷重 $T_{c}=0.4 T_{\max }=20 \mathrm{kN} / \mathrm{m} ）$

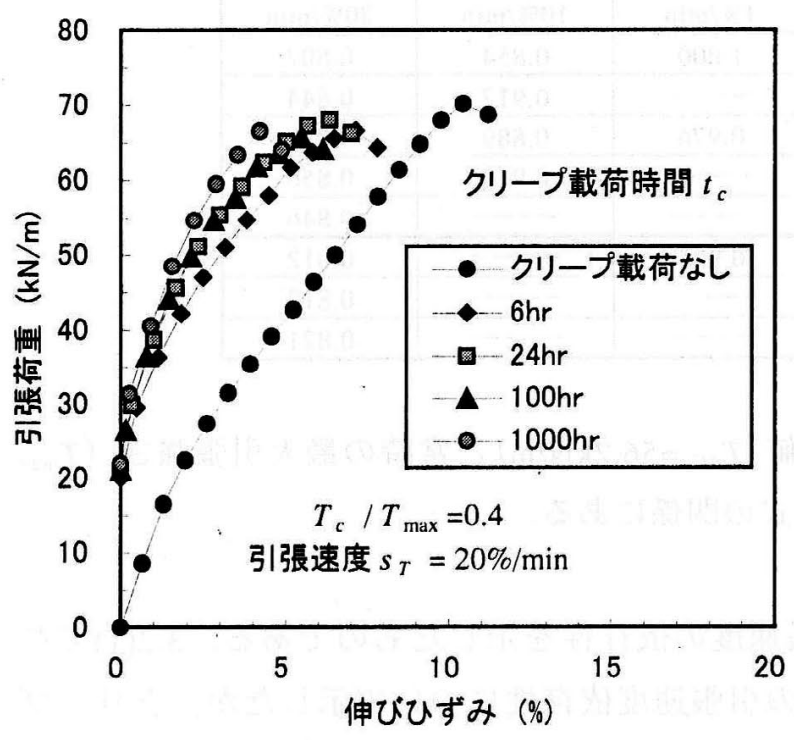

図-5 クリープ載荷試験後の引張特性

（載荷荷重 $T_{c}=0.4 T_{\max }=20 \mathrm{kN} / \mathrm{m}$ ）

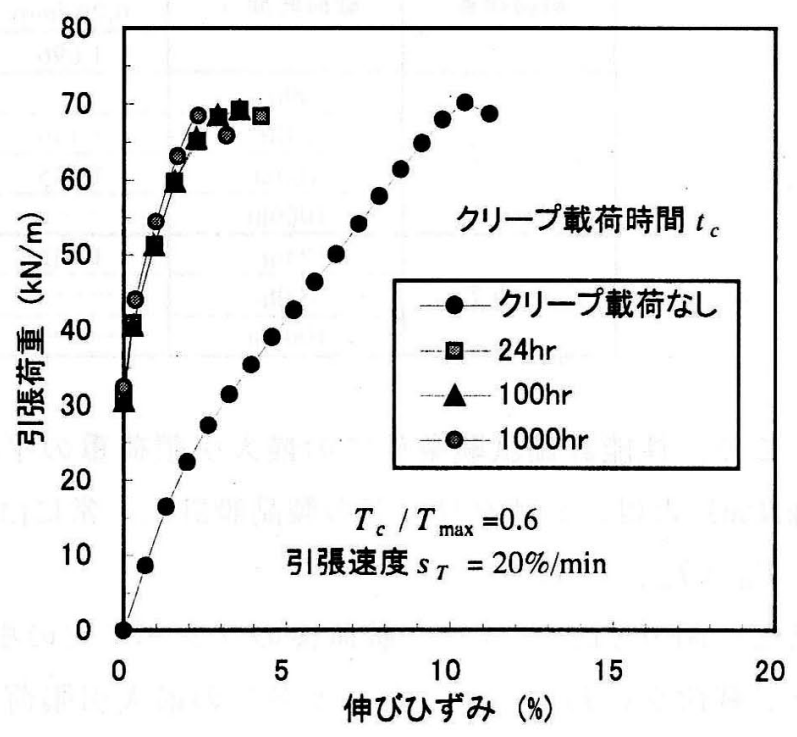

図-6クリープ載荷試験後の引張特性

（載荷荷重 $T_{c}=0.6 T_{\max }=30 \mathrm{kN} / \mathrm{m}$ ) 


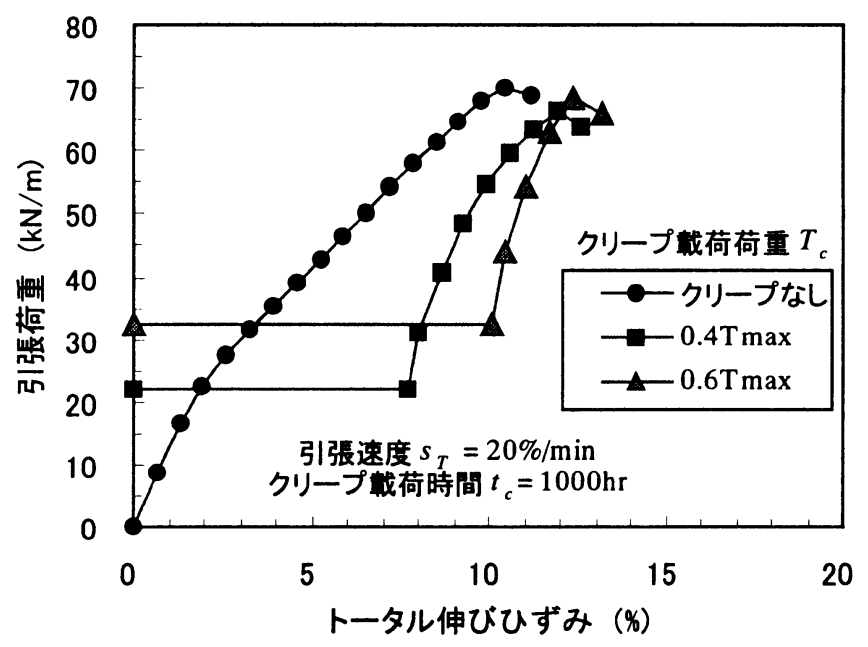

図-7 クリープ載荷試験後の引張特性 (クリープ載荷時間 $t_{c}=1000 \mathrm{hr}$ )

表-4 は, クリープ荷重を載荷しない性能評価試験（引張速度 $1 \% / \mathrm{min}$ ）条件での引張試験の最大引張 荷重の平均值 $\left(T_{A V}=56.2 \mathrm{kN} / \mathrm{m}\right)$ とクリープ載荷後の引張試験より得られた最大引張荷重（ $T_{E} ）$ との比 $\left(T_{A V} / T_{E}\right)$ を示したものである． また，表-4 の值のうち, 引張速度が $20 \% / \mathrm{min}$ でのケースの試験結果を 図示したものが図-8 である。図-8 および表-4に記載した通り,引張速度 $20 \% / \mathrm{min}$ の条件での $\left(T_{A V} / T_{E}\right)$ 比の值は, クリープ載荷荷重 $T_{c}$ の大きさやクリープ載荷時間の長さ $t_{c}$ に関わらず, $0.8 \sim 0.9$ の範囲に あることがわかる.

表-4 性能評価試験の最大引張荷重 $\left(T_{A V}\right)$ とクリープ載荷後の最大引張荷重 $\left(T_{E}\right)$ との比 $\left(T_{A V} / T_{E}\right)$

\begin{tabular}{|c|c|c|c|c|c|}
\hline \multirow{2}{*}{ 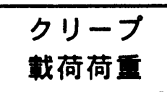 } & \multirow{2}{*}{$\begin{array}{c}\text { クリープ } \\
\text { 嗔荷時間 } t_{c}\end{array}$} & \multicolumn{4}{|c|}{ 引張速度 $s_{T}$} \\
\hline & & $0.2 \% / \mathrm{min}$ & $1 \% / \mathrm{min}$ & $10 \% / \mathrm{min}$ & $20 \% / \mathrm{min}$ \\
\hline - - & $-\square$ & 1.096 & 1.000 & 0.854 & 0.802 \\
\hline \multirow{4}{*}{$T_{c}=0.4 T_{\max }$} & $6 \mathrm{hr}$ & - - & - - & 0.912 & 0.844 \\
\hline & $24 \mathrm{hr}$ & 1.149 & 0.976 & 0.889 & 0.827 \\
\hline & $100 \mathrm{hr}$ & 1.115 & -二- & 0.910 & 0.856 \\
\hline & $1000 \mathrm{hr}$ & - - & -二 & - - & 0.846 \\
\hline \multirow{3}{*}{$T_{c}=0.6 T_{\max }$} & $24 \mathrm{hr}$ & 1.142 & 0.985 & -二- & 0.812 \\
\hline & $100 \mathrm{hr}$ & - - & - - & - & 0.813 \\
\hline & $1000 \mathrm{hr}$ & -- & -- & -—- & 0.821 \\
\hline
\end{tabular}

ここで, 性能評価試験条件での最大引張荷重の平均値 $\left(T_{A V}=56.2 \mathrm{kN} / \mathrm{m}\right)$ と常時の最大引張強さ（ $T_{\max }$ $=50 \mathrm{kN} / \mathrm{m}$ ）とは，ジオグリッドの製品設計上，常に(3.1)式の関係にある.

$$
T_{A V}>T_{\max }(3.1)
$$

また, 図-9 は, クリープ載荷後のサンプルでの引張速度の依存性を示したものである. 3.2(1)でク リープ載荷を行わないジオグリッドでの最大引張荷重の引張速度依存性について示したが，クリープ 載荷後であっても同様に最大引張荷重 $\left(T_{E}\right)$ は, 引張速度が速いほど大きな值となり, $\left(T_{A V} / T_{E}\right)$ 值は, 引張速度が速いほど小さな值となる. したがって, 実際の地震時の引張速度での最大引張強さ $\left(T_{E \max }\right)$ と比較的低速な引張速度条件での最大引張荷重の間には，(3.2)式の関係があると考えられる. 


$$
T_{E \max }>T_{E}\left(s_{T}=20 \% / \mathrm{min}\right) \quad(3.2)
$$

図-8に示した実験結果の $\left(T_{A V} / T_{E}\right)$ 值が $0.8 \sim 0.9$ の範囲にあること, さらに，(3.1)および(3.2)式の関 倸より, 地震荷重に対する材料安全率は, (2.5)'式のような範囲にあると考えられ, 材料安全率 $F_{E}$ の 值としては 0.9 を見込めば安全側の值であるものと考えられる.

$$
F_{E}=\frac{T_{\max }}{T_{E \max }}<\frac{T_{A V}}{T_{E}}=0.9
$$

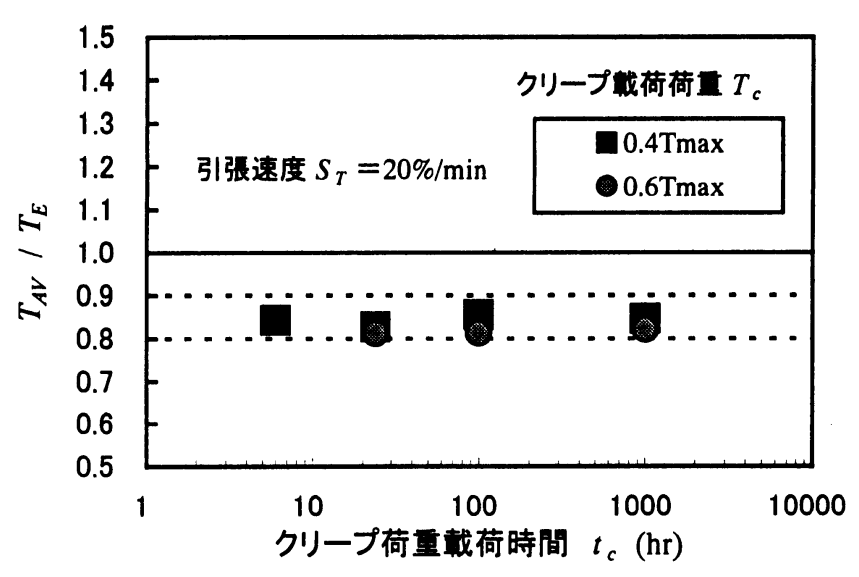

図-8 最大引張荷重 $\left(T_{A V}\right)$ とクリープ載荷後の 最大引張荷重 $\left(T_{E}\right)$ との比 $\left(T_{A V} / T_{E}\right)$

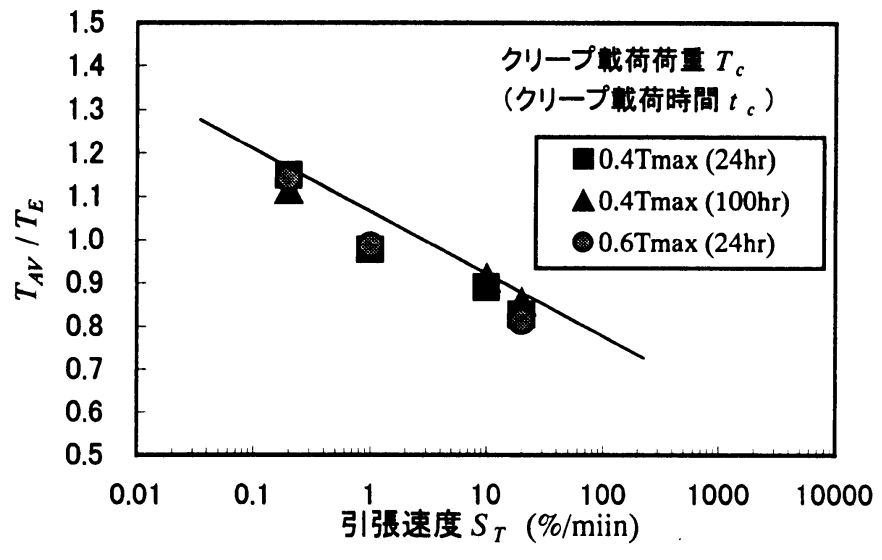

図-9 クリープ載荷後のジオグリッドの 引張速度依存性

(4) 地震時の割增係数 $\lambda$

2.2 で述べたように, ジオグリッドの常時設計用の設計引張強さに対する耐震設計用の設計引張強 さ割增し係数入は，(2.6)式のように表される.

$$
\lambda=\frac{F_{c r}}{F_{E}}(2.6)
$$

一方, 試験に使用した表-1 の特性值を持つジオグリッドでは, 通常のクリープ試験結果から求めた

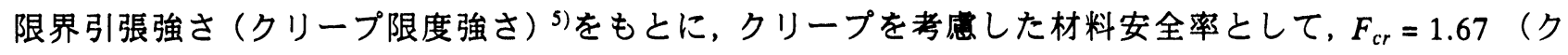
リープ低減係数 $\mu=0.6 ）$ の值を用いている. ここで, (2.6)式に $F_{E}=0.9, F_{c r}=1.67$ の值を代入するこ とにより, 割增し係数 $\lambda$ の值として $\lambda=1.86$ が得られる.

以上の結果から耐震設計に用いる設計引張強さの常時設計に用いる設計引張強さに対する割增係数 $\lambda$ の值は, クリープを考慮した材料安全率 $\left(F_{c r}=1.67\right)$ 程度の值を用いることができると考えられる. 
4. おわりに

今回, 高密度ポリエチレン一軸延伸タイプのジオグリッドについて, 耐震設計に用いる設計引張強 さに影響を与えると考えられる要因について検討を行った．結果をまとめると以下の通りである.

(1) 引張試験における最大引張荷重は, 引張速度 $\left(s_{T}\right)$ の影響を大きく受け, 引張速度が速いほど, 最大引張荷重は大きな值を示す. 地震時の引張速度は, 今回実施した引張速度（最大 $20 \% / \mathrm{min}$ ） よりも速いことが予想されるが, 今回の評価には, 引張速度 $20 \% / \mathrm{min}$ の条件を用いた.

(2) 常時の設計引張強さ以下の引張荷重の範囲(クリープによる破壊を起こさない荷重の範囲)では, 地震時の最大引張強さを求める上での, クリープ現象を生じさせる常時の荷重 (クリープ載荷荷 重 $T_{c}$ ) およびクリープ現象が継続する時間（クリープ載荷時間 $t_{c}$ ）の影響は, ほとんどないと考 えられる。

(3) 耐震設計に用いる設計引張強さの常時設計に用いる設計引張強さに対する割増係数入の值は, ク リープを考慮した材料安全率（ $F_{c r}=1.67 ）$ 程度の值を用いることができると考えられる．言い 換えれば，耐震設計においては，クリープによる強度低減を見込む必要はないと考えられる.

なお，今回の一連のケースでは，クリープ載荷後の引張試験を一定引張速度の静的載荷条件で実施 した．今後, 次のシリーズとして, 繰り返し載荷による影響などについて検討する予定である.

謝辞: 末筆ながら, 今回の一連の実験を計画するにあたり, 建設省土木研究所 松尾修室長, 中村伸也 主任研究員に貴重な御助言を賜ったこと, 深く謝意を表します.

\section{参考文献}

1) ジオテキスタイル補強土工法普及委員会編 : ジオテキスタイルを用いた補強土の設計・施工マニ ユアル (改訂版), 財団法人 土木研究センター, p.269, 2000.2

2) 山内豊聡, 福田直三, 周藤宜二 : ポリマーグリッドの設計強度の評価試験, 第 30 回土質工学シン ポジウム発表論文集, 社団法人 土質工学会, pp.23 26,1985.11

3) ジオテキスタイル補強土工法普及委員会編 : ジオテキスタイルを用いた補強土の設計・施工マニ ユアル (改訂版)，財団法人 土木研究センター, pp.47-48, 2000.2

4) ジオテキスタイル補強土工法普及委員会編 : ジオテキスタイルを用いた補強土の設計・施工マニ ユアル (改訂版), 財団法人 土木研究センター, p.22, 2000.2

5) ジオテキスタイル補強土工法普及委員会編 : ジオテキスタイルを用いた補強土の設計・施工マ二 ユアル（改訂版），財団法人 土木研究センター, p.25-28, 2000.2 